\title{
Liberty for More: \\ Finance and Educational Opportunities
}

\author{
Ross Levine and Yona Rubinstein*
}

August 2013

\begin{abstract}
Banking reforms - that reduced interest rates - boosted college enrollment rates among able students from middle class families. We define "able" students as those with learning aptitude scores in the top two-thirds of the U.S. population. We define "middle class" as families in which both parents are not highly-educated (above 12 years of education) and that are neither in the bottom fourth nor in the top 10 percent of the distribution family income in the U.S. Our findings suggest that credit conditions, the ability of an individual to benefit from college, and a family's financial and educational circumstances combine to shape college decisions. The functioning of the financial system plays a powerful role in shaping the degree to which a child's educational choices - and hence economic opportunities - are defined by parental income.
\end{abstract}

*Levine: Haas School of Business at the University of California, Berkeley; Milken Institute, and the NBER; ross_levine@haas.berkeley.edu. Rubinstein: London School of Economics, y.rubinstein@1se.ac.uk. We thank Carlos Avenancio, Maria Carkovic, Raquel Fernandez, Erica Field, Bob Hall, Jeff Smith, and seminar participants at the Third Annual Cato Papers on Public Policy Conference for very helpful comments and suggestions. 


\section{Introduction}

Consider two observations about education and income. First, there is a positive association between education and income. On average, people who receive more education go on to earn higher incomes. Second, there is a positive association between parental income and the education of their children. Thus, higher-income parents tend to have children that receive more education and this additional education is associated with those children earning higher incomes as adults. ${ }^{1}$

These two observations motivate a hotly debated question among social scientists: If the returns to education are so high, why do children from lower-income families obtain less education than children from higher-income families? If education boosts future incomes, what constrains children from lower-income families from attaining more education?

One view focuses on the costs: lower-income families do not have the money - and borrowing is too expensive - to pay for more (Becker, 1975; Kane, 1994; Kane and Rouse, 1999; Ellwood and Kane, 2000; Belley and Lochner, 2007; Brown, Scholz and Seshadri, 2007). From this perspective, financial reforms that lower interest rates will boost education, including college enrollment rates, among children from disadvantaged families that were unable to afford college when credit was more expensive.

A second view stresses the benefits: the returns to higher education for children from disadvantaged families are comparatively low, and so they invest less in education (Cameron and Heckman, 1998, 2001; Shea 2000; Keane and Wolpin, 2001; Carneiro and Heckman, 2002; Keane 2002). That is, if children from lower-income families experience family, community, and grade school environments that are less conducive to their cognitive and noncognitive development than children from higher-income families, then their expected benefits from attending college will be

\footnotetext{
${ }^{1}$ See Behrman and Taubman (1990) Hauser (1993), Kane (1994), Mayer (1997), Manski and Wise (1983), Cameron and Heckman (1998, 2001), Shea (2000), and Carneiro and Heckman (2002).
} 
corresponding lower. Consequently, by the time students are deciding whether to work or go to college, their childhood environments have already determined their expected benefits from going to college. From this perspective, financial reforms that reduce the cost of credit will have a minor effect as disadvantaged families accurately view the expected benefits as low. ${ }^{2}$

To assess these views empirically, numerous empirical studies use indirect methods - that do not rely on directly observing interest rates - to infer whether interest rates materially shape educational choices because of the difficulties associated with identifying exogenous changes in interest rates. As we review in greater detail below, a large body of research devoted to estimating the causal effects of schooling on income (see Card, 1999, 2001) has found that the instrumental variable estimates of the returns to schooling exceed the OLS estimates. In theory, credit constrained individuals will have higher returns to education on the margin than less constrained individuals. This implies that if the instrumental variables capture the schooling choices of credit constrained individuals more than others, the instrumental variable estimates will be larger (Lang, 1993; Card 1999, 2001). However, it might be inappropriate to interpret the differences between IV and OLS estimates as reflecting the impact of the cost of credit on educational choices since other factors can produce these differences (Carneiro and Heckman, 2002; Cameron and Taber, 2004).

A second, but much more limited body of research, directly assesses the impact of interest rates on education, but there are serious methodological limitations with this line of inquiry too. In an influential study, Card and Lemieux (2001) find that changes in U.S. interests do not account for changes in educational choices over the period from 1968 to 1996. But, it is inappropriate to treat the United States as an integrated capital market with a single interest rate during the 20th century with corresponding effects on state-level interest rates. State bank regulations differentially

\footnotetext{
${ }^{2}$ Rather than focusing on reducing the cost of credit, this "benefits" view holds that the most efficacious way to boost college graduation rates among lower-income families is through early childhood interventions that enhance cognitive and noncognitive development and thereby boost the returns to education.
} 
influenced the cost of credit in each state. And, states reformed their regulations in different years during the second half of the $20^{\text {th }}$ century. Consequently, both the level and dynamics of interest rates differ across states. Furthermore, since many factors might be correlated with both interest rates and education, it is important to use instrumental variables to identify the impact of interest rates on education.

By integrating labor and financial economics, we contribute to the study of the impact of credit conditions on educational choices in several ways. First, we assess whether state-specific banking reforms that intensified competition among banks and reduced state-specific interest rates increased the probability that students from those states attended college. Previous research on education and credit conditions both failed to recognize that U.S. credit markets were highly segmented due to state-specific regulations on banks for virtually the entire 20th century and failed to exploit the cross-state heterogeneity in the timing of banking reforms that lowered interest rates. In one of the largest, if not the largest, financial regulatory reform in the history of the United States, every state relaxed geographic restrictions on bank branching —intrastate bank branching reform — during the second half of the $20^{\text {th }}$ century, where the state-specific timings of these deregulations were independent of interest rates and education. Although these intrastate bank branch deregulations eased credit conditions, researchers have not — to the best of our knowledgepreviously assessed the impact of these regulatory reforms on educational choices.

Second, using state-level bank branch deregulation as an instrumental variable for interest rates, we assess whether this component of state-level interest rates affects the probability that students from that state attend college. However, one must be cautious in drawing sharp inferences from the IV analyses, since bank branch deregulation does not necessarily satisfy both conditions for a valid instrument. Although there is no evidence that educational choices or interest rates 
influence the timing of bank deregulation in a state, the exclusionary condition might not hold. For example, bank deregulation might accelerate economic activity and boost the demand for skilled workers, encouraging more students to attend college. Put differently, exogenous bank branch deregulation might reduce interest rates and boost college enrollment rates, but it might not boost college enrollments by lowering interest rates; it might boost college enrollments by increasing the demand for skilled workers. Thus, to interpret the instrumental variable analyses as providing information about the impact of an exogenous change in the cost of borrowing on the decision to attend college, we separately evaluate whether demand side factors are driving the results.

Third, we assess whether an easing of credit conditions triggered by intrastate bank branch deregulation influenced only those particular children within particular families implied by Becker's (1967) model of human capital accumulation. The model suggests that the impact of lowering interest rates on attending college depends in an interactive manner on family income and the ability of the individual child to benefit from college. This framework suggests that a reduction in interest rates will have a larger impact on high-ability students that would benefit materially from college but whose parents were previously unable to afford college than it will on high-ability children from families that are unconstrained when making decisions about college. Thus, the model predicts that the impact of a change in credit conditions will differ depending on the ability of the individual student to benefit from college and on the ability of the family to pay for college. We assess this prediction using both the simple reduced form analyses of education and bank deregulation and the IV analyses that use bank deregulation as an instrument for interest rates.

To make these contributions, we primarily use the National Longitudinal Survey of Youths, 1979 (NLSY79) because of its unique characteristics. First, the NLSY79 traces individuals through time, so that we know the educational attainment of each person. Second, the NLSY79 contains 
information on learning aptitude. It gave respondents the Armed Forces Qualifications Test (AFQT) in 1980 when they were between the ages of 15 and 22. We use the AFQT score as a measure of learning ability, i.e., ability to benefit from education. Third, the NLSY79 has information about each respondent's family, including family income in 1979 and the educational attainment of both the mother and father. Given the tight connection between education and income and the problems associated with measuring permanent income using only one year of data, we sometimes use parental education as a proxy measure of the permanent income of the family instead of family income in 1979. Fourth, the NSLY79 has information two psychometric traits, as measured in 1980 self-esteem and the degree to which the person believes that chance, fate, and luck control their lives. Thus, in assessing the impact of changes in credit conditions on educational choices, we can control for many individual and family characteristics. To complement the NLSY79, we use the Current Population Survey (CPS), which surveys more people than the NLSY79 but it does not information on learning ability, parental education, or personality traits. Thus, we use the CPS to make broader assessments about the impact of bank deregulation on interest rates and the Mincerian returns to education and the NLSY79 to assess how changes in credit conditions influence the decision of individuals to attend college.

We find that intrastate bank deregulation substantially increased the probability that individuals with particular learning abilities and family traits attended college. Specifically, bank deregulation had no effect on students in the lower third of the distribution of learning ability, as measured by AFQT: for students where the expected benefits of college are low, changes in credit conditions have no appreciable effect on the probability of attending college. But, bank deregulation did boost the probability that "able" students—students in the upper two-thirds of the AFQT distribution - go to college. For example, five years after a state deregulated, the probability that 
able students attend college was 13 percent greater than before deregulation. Moreover, and consistent with theory, it is the able students from families in which both parents have a relatively low level of education (less than 12 years of completed schooling) that an easing of credit conditions has the biggest impact. Indeed, for able students from families in which both parents have more than 12 years of education, bank deregulation has no effect. To the extent that parental education is an accurate signal of the family's permanent income (or the family's taste for education), changes in credit conditions do not have much of an influence on the decisions highlyeducated, affluent parents to send their children to college. However, in more disadvantaged families (as measured by parental education), bank deregulation has a large effect: five years after deregulation, able students from disadvantaged families have an almost 20 percent greater probability of attending college. The results are consistent with the view that credit conditions materially influence the educational opportunities of a particular segment of society: able students from disadvantaged families.

When dividing the sample by family income instead of parental education, we find that easing intrastate bank deregulation boosted college enrollment rates among able students from middle and upper-middle class families. Even among students in the upper two-thirds of the AFQT distribution, an easing of credit conditions did not influence children from lower-income families (below the $25^{\text {th }}$ percentile of the income distribution) or high-income families (above the $90^{\text {th }}$ percentile). At these income levels, marginal changes in interest rates did not alter decisions about college. However, for able students from families with incomes between the $50^{\text {th }}$ and $75^{\text {th }}$ percentile of the income distribution, bank deregulation materially altered college decisions.

The results are very similar when we use bank deregulation as an instrumental variable for interest rates. Only for able students from middle and upper-middle class families is the reduction in 
interest rates associated with an increase in the probability of attending college. For lower-income families or high-income families, such changes in the cost of credit do not influence college decisions. And, reductions in interest rates do not increase the probability of attending college among students with AFQT scores in the bottom third of the sample. Consistent with theory, changes in the cost of credit influence a particular, but meaningful, segment of society.

Finally, we show that our results do not simply reflect the impact of intrastate bank deregulation on the demand for skilled labor; rather, bank deregulatory reforms boosted college enrollment rates among able students from middle and upper-middle class families at partially by lowering the costs of credit. In particular, a legitimate concern with our analyses is that perhaps branch deregulation boosted economic activity (Jayaratne and Strahan, 1996) and thereby boosted the demand for skilled labor. Perhaps, this "demand side" effect is driving the increase in college enrollments and we have misinterpreted the findings as arising from a reduction in the "cost of credit." While reasonable conceptually, the "demand side" channel is not the only channel through which bank deregulation increased college enrollments. If the results were purely a demand side effect, then bank deregulation should boost the demand for college-educated workers and the returns to a college education. But, we show that that bank deregulation reduced the returns to a college education, which is fully consistent with a reduction in costs boosting the supply of collegeeducated workers. Although we do not rule out the demand-side channel as a contributing factor, the findings suggest that the supply side mattered too, as deregulation eased credit conditions and this boosted the supply of college-educated workers.

The remainder of the paper is organized as follows. Section 2 sketches the theoretical framework and its empirical predictions. Section 3 provides a literature review and details how we 
propose to contribute to existing research. In section 4, we discuss the data on bank deregulation, interest rates, and education. Section 5 presents the results and section 6 concludes.

\section{Theoretical Framework and Empirical Predictions}

Building directly on Becker (1967) and Mincer (1974), this section first presents a theoretical model of human capital and then details the empirical predictions emerging from the theory. In its simplest form, the Becker (1967) model assumes that each individual $i$ maximizes the discounted present value of lifetime earnings, $W\left(s_{i}\right)$, by choosing the optimal level of investment in human capital, $s_{i}$, which we call "schooling" or "education" but which represents all investments in human capital skills that boost earnings.

$$
W\left(s_{i}\right)=\int_{t=s}^{\infty} y\left(s_{i}\right) \exp \left(-\left(r_{i}-\theta_{i}\right)\right) d t
$$

where $y\left(s_{i}\right)$ denotes the annual earnings of an individual with a schooling level $s_{i}, r_{i}$ is the interest rate facing individual $i$, which reflects her cost of capital and subjective rate of time preference, and $\theta_{i}$ is the individual's preference for schooling over work. For simplicity, we assume an infinite planning horizon.

To complete the model, let earnings reflect the spot market value of a unit of human capital $(P)$ multiplied by the individual's stock of accumulated human capital $\left(H\left(s_{i}\right)\right)$ :

$$
y\left(s_{i}\right)=P^{*} H\left(s_{i}\right) .
$$

Further, following Grilliches (1977) and more recently Card (2001), define the human capital production function as follows:

$$
H\left(s_{i}\right)=\exp \left(a_{i} s_{i}-\frac{\gamma}{2} s_{i}^{2}+\mu_{i}\right)
$$


where individual $i$ 's human capital is positively related to her schooling $\left(s_{i}\right)$, ability to benefit from schooling $\left(a_{i}\right)$ and initial level of general skills $\left(\mu_{i}\right)$. The beneficial effects of additional schooling face diminishing returns $(\gamma)$, which we assume to be the same across all individuals for simplicity. Solving, the optimal level of schooling for individual $i\left(s_{i}^{*}\right)$ is

$$
s_{i}^{*}=\frac{a_{i}-r_{i}+\theta_{i}}{\gamma} .
$$

Across individuals, differences in the optimal amount of education reflect differences in the ability to benefit from education $\left(a_{i}\right)$-modeled as the technological efficiency with which learning time, effort and resources augment the value of human capital, the cost of credit $\left(r_{i}\right)$, and the (dis)utility from schooling $\left(\theta_{i}\right)$. Clearly, if an individual's marginal benefit from education in terms of future income is relatively large (i.e., a large $a_{i}$ ), then this individual will tend to invest relatively more in schooling than a low-ability person. And, if an individual's preference for education, $\theta_{i}$, is relatively high, then such an individual will invest more in education than comparable individuals with weaker tastes for schooling. The model is silent about the source of heterogeneity in the "ability to benefit" from education (Ben Porath, 1967) and the "ability to pay." Separating between the ability to benefit from education and the ability to pay for it is challenging, especially since family and community environments affect both.

While it is appropriate to model human capital as a stock and investment in human capital as a flow, schooling — especially higher level education—is often a discrete choice. Therefore, there are discrete educational choices, such as attending college, for which the impact of easing credit conditions will depend on the initial conditions facing the family and individual student. For example, a high-ability student in a high-income family that has a strong taste for education might have an optimal level of schooling that includes college and even a postgraduate degree. In this 
case, lowering interest rates will not affect the decision to attend college. As another example, a low-ability student from a disadvantaged family with weak tastes for education might have an optimal level of schooling that does not even include graduating from high school. In this case, lowering interest rates is unlikely to affect the decision to attend college. However, for some highability children from families in which initial interest rates cause the expected costs of college to outweigh the expected benefits, an easing of credit conditions could influence the decision to go to college. Thus, the impact of credit conditions on the decision of an individual student in a particular family to attend college may depend materially on the student's ability to benefit from college and the initial financial conditions facing the family and its taste for education.

\section{The Literature and Our Contribution}

\subsection{Debates}

Why do lower-income families not invest more in the education of their children? An enormous literature documents large disparities in high school and college graduation rates across family income groups over the $20^{\text {th }}$ century (Behrman and Taubman, 1990; Hauser, 1993; Kane, 1994; Mayer, 1997; Manski and Wise, 1983; Cameron and Heckman, 1998, 2001; Shea, 2000; Caneiro and Heckman, 2002). Since education is so highly correlated with income, this motivates research on the persistence of inter-income group disparities in education.

As the model highlights, there are two major, though not mutually exclusive, explanations for why disadvantaged families invest comparatively little in the education of their children. The first emphasizes the costs: lower-income families do not have the money to pay for more education and their borrowing costs are high. These costs hinder lower-income families from providing the same level of education to their kids as higher-income families, perpetuating intergenerational 
income differences. From this perspective, lowering interest rates will lower the costs of education, so that high-ability children from lower-income families can now afford college. Thus, improvements in financial systems can reduce inequalities of opportunity and the inefficient persistence of relative income differences.

The second explanation of why lower-income families do not invest more in education stresses the benefits: the children of disadvantaged families frequently face lower expected returns to additional education, i.e., their $a_{i}$ 's are low. According to this view, family, community, and school environments affect the cognitive and non-cognitive development of children and hence the ability of those children to benefit from a college education. That is, by the time children are deciding about whether to work or go to college, the expected benefits of college have largely been determined. Thus, children from disadvantaged families, which tend to provide family, community, and school environments less conducive to the cognitive and noncognitive development of their children, will disproportionately, and accurately, view college as a relatively low-return activity. From this perspective, lowering interests rates will not induce lower-income families to invest much more in sending the kids to college. 


\subsection{Existing Evidence}

The evidence on whether the credit conditions influence educational choices is mixed and inconclusive. Given the difficulties associated with measuring the credit conditions facing individuals, a large body of research has used indirect methods - that do not require researchers to observe interest rates or other measures of credit conditions - to draw inferences about the influence of credit conditions on educational choices.

Numerous studies have tackled this question by studying the correlation between educational attainment and family income (or other family characteristics). The positive correlation between educational attainment and family income has been widely interpreted as evidence that borrowing constraints hinder educational choices (see for example: Kane, 1994; Kane and Rouse, 1999; Ellwood and Kane, 2000; Belley and Lochner, 2007; Brown, Scholz and Seshadri, 2012). However the step from correlation to causation is a precarious one as family income is also strongly correlated with family resources that foster cognitive and non-cognitive traits that boost the ability of a student to benefit from more education. The connection between family resources and the nurturing of cognitive and noncognitive traits that increase the productivity of formal schooling has been emphasized by Cameron and Heckman, 1998, 2001; Shea 2000; Keane and Wolpin, 2001; Carneiro and Heckman, 2002; Heckman and Rubinstein, 2001; Heckman, Stixrud, and Urzua, 2006; Keane 2002 and Cameron and Taber, 2004.

In addition, a large literature finds that the instrumental variables (IV) estimates of the return to schooling exceed OLS estimates (see Card, 1999, 2001). Credit conditions are one possible source of this difference between IV and OLS estimates, a point first offered by Becker (1967). In particular, instrumental variables estimates can be interpreted as estimating the return for those randomly assigned to schooling by the instrument. Finding higher returns using IV is consistent 
with the view that that those affected by the "instrument" are credit constrained (Lang, 1993; Card, $1999,2001)$ and therefore consistent with interest rates curtailing the educational opportunities of lower-income families. Similarly, Shea (2000) finds that family income matters for children's human capital investment in a sample of low-income families, but not for the broader population. ${ }^{3}$

Substantial work, however, challenges the methodological efficacy of these indirect methods for drawing inferences about the impact of credit conditions on educational choices. For example, Heckman (1995), Cameron and Heckman (1998, 2001), and Carneiro and Heckman (2002) suggest that it is inappropriate to interpret the difference between OLS and IV estimates in the sample of low-income families as signaling the importance of liquidity constraints, criticizing econometrically the use of invalid instruments and pointing, economically, for alternative explanations including sorting to schooling on comparative advantage.

Hence, larger coefficients in IV regressions of income on education might not imply the existence and impact of interest rates on schooling. That is, without directly measuring exogenous changes in interest rates, it is difficult to distinguish between cross-family differences in interest rates $\left(r_{i}\right)$ and attitudes toward education $\left(\theta_{i}\right)$. Furthermore, Cameron and Taber (2004) question the robustness of the instrumental variable results to using alternative instruments, and Keane and Wolpin (2001) estimate a structural model of schooling behavior and find that relaxing interest rates tends to increase consumption, not investment in education

A much more limited set of papers assesses the direct linkage between interest rates and schooling decisions. As a leading example, Card and Lemieux (2001) find that changes in U.S. interest rates over the period from 1968-1996 do not account for changes in educational choices.

\footnotetext{
${ }^{3}$ Researchers also examine the impact of targeted credit programs on education, such as the CalGrant program in California for college bound students (Kane, 2003) or Headstart.
} 
However, there are two key limitations with the direct approaches taken so far. First, it is inappropriate to treat the United States as an integrated capital market with a single interest rate, especially with regards to household loans during the $20^{\text {th }}$ century. Each state exerted a powerful regulatory role over banks until the mid-1990s, so that interest rates, and their evolution over time, differ markedly by state. Second, it is valuable to identify an exogenous source of variation in credit conditions to assess the impact of interest rates on educational choices. Some third factor, such as aggregate economic activity, could affect both interest rates and education decisions, creating a spurious correlation between them.

\subsection{Our Contribution}

We propose to contribute to existing research in the following interrelated ways. First, we will directly examine the relationship between educational choices and credit conditions, as measured by exogenous changes in bank regulations that lowered interest rates. This contrasts with the large literature that draws inferences about the importance of credit conditions in explaining educational choices through indirect methods, i.e., by examining differences between IV and OLS coefficient estimates of the relationship between wages and education.

Second, we will assess the impact of the exogenous relaxation of regulatory restrictions on bank branching — that lowered interest rates — on college enrollment rates. As we describe in greater detail below, these deregulations occurred across all states in varying years during the second half

of the $20^{\text {th }}$ century. Since these state-level regulatory reforms occurred in different years, we control for all national influences by including year fixed effects. Furthermore, whereas past studies take the United States as an integrated financial system with one interest rate, we allow interests rates to differ at the state-year level. This is crucial for drawing accurate inferences about the relationship 
between credit conditions and educational choices because state regulations heavily and differentially influenced credit conditions across the U.S. states for much of the $20^{\text {th }}$ century and these regulations were liberalized in different years in different states.

Third, we assess the relationship between interest rates and college enrollment rates, using exogenous cross-state, cross-year variation in bank deregulation as an instrumental variable (IV) for interest rates. Unlike much existing work, it is valuable to use instrumental variables because interest rates and schooling choices might be simultaneously determined. In these analyses, we argue that bank deregulation is exogenous to educational choices, but we do not claim that bank deregulation influences schooling only through its effect on interest rates; we do not claim that bank deregulation satisfies the exclusionary restriction. In particular, bank deregulation might boost the demand for skilled workers and thereby induce more people to attend college. Despite these limitations, we present evidence that deregulation boosted college enrollment rates by reducing the cost of college, not simply by increasing the demand for skilled workers.

Fourth, we provide an empirical bridge between those that focus on the costs of education and those that focus on the benefits of education in seeking to explain why the children of lowerincome families tend to obtain less education. To do this, we will evaluate the impact of easing credit conditions ("costs of education") on an individual's educational choices while differentiating by proxies for (1) the person's learning aptitude ("benefits of education") and (2) the family's initial conditions as measured by family income and the education of the parents. Thus, we will assess how the costs and benefits of college combine to shape an individual's educational choices. ${ }^{4}$

\footnotetext{
${ }^{4}$ Furthermore, by differentiating by each individual's cognitive abilities and the traits of each person's parents, the framework advertises an addition line of inquiry: Credit conditions can influence the ability of a person to benefit from college. For example, if a reduction in interest rates allows a family to purchase a home in a better school district and this school district enhances the cognitive and noncognitive capabilities of the children, then interests can increase the returns from additional education for these children: a reduction in $r_{i}$ can boost $a_{i}$, with a concomitant increase in education and lifetime earnings. We are pursuing this line of research in a companion paper.
} 


\section{Data: Bank Deregulation, Interest rates, and Education}

\subsection{History and timing of bank deregulation}

Geographic restrictions on banks have their origins in the U.S. Constitution, which limited states from taxing interstate commerce and issuing fiat money. In turn, states raised revenues by chartering banks and taxing their profits. Since states received no charter fees from banks incorporated in other states, state legislatures prohibited the entry of out-of-state banks through interstate bank regulations. To maximize revenues from selling charters, states also effectively granted local monopolies to banks by restricting banks from branching within state borders. These intrastate branching restrictions frequently limited banks to operating in one city.

By protecting inefficient banks from competition, geographic restrictions created a powerful constituency for maintaining these regulations even after the original fiscal motivations receded. Indeed, banks protected by these regulations successfully lobbied both the federal government and state governments to prohibit interstate banking and intrastate branching (White, 1982).

In the second half of the 20th century, however, technological, legal, and financial innovations diminished the economic and political power of banks benefiting from geographic restrictions. In particular, a series of innovations lowered the costs of using distant banks. This reduced the monopoly power of local banks and weakened their ability and desire to lobby for geographic restrictions. For example, the invention of automatic teller machines (ATMs), in conjunction with court rulings that ATMs are not bank branches, weakened the geographical link between banks and their clientele. Furthermore, the creation of checkable money market mutual funds made banking by mail and telephone easier, thus further weakening the power of local bank monopolies. Finally, the increasing sophistication of credit scoring techniques, improvements in 
information processing, and the revolution in telecommunications reduced the informational advantages of local bankers, especially with regards to small and new firms.

These national developments interacted with preexisting state characteristics to shape the timing of bank deregulation across the states, which are listed in Table 1. As shown by Kroszner and Strahan (1999), deregulation occurred later in states where potential losers from deregulation (small, monopolistic banks) were financially stronger and had a lot of political power. On the other hand, deregulation occurred earlier in states where potential winners of deregulation (small firms) were relatively numerous.

Thus, unlike many types of regulatory reforms that occur at the national level, geographic bank deregulation took place on a state-by-state basis over an extended period. Table 1 lists the timing of these reforms across the 50 states plus the District of Columbia. For example, we often use the number of years since a state deregulated intrastate branch banking in 1979, which has a mean value of 3.6 and a standard deviation of 7.1, as shown in Table 2.

\subsection{Interest rates}

To measure the cost of credit, we use data on mortgage rates at the state-year level. Since consumers frequently use homes as collateral, these rates provide information on general credit conditions. The mortgage interest rate data are based on a monthly survey of major lenders that are asked to report the terms and conditions on all conventional, single-family, fully amortized, purchase-money loans closed in the last five working days of the month. The data excludes FHAinsured and VA-guaranteed mortgages, refinancing loans, and balloon loans. The "effective interest rate" includes the amortization of initial fees, points, and charges over a 10-year period, which is the 
historical assumption of the average life of a mortgage loan and is computed by the Federal Housing Finance Board. We then deflate by the national consumer price index.

\subsection{Education and other individual level data}

We primarily use the National Longitudinal Survey of Youth (NLSY79). The NLSY79 is a nationally representative sample of 12,686 young men and women who were 14-22 years old when they were first surveyed in 1979. Interviewees have been surveyed annually since the initial wave of the survey and on a biennial basis after 1994. The NLSY is made up of three subsamples: (1) a random sample of 6,111 non-institutionalized civilian youths, (2) a supplemental sample of 5,295 youths designed to oversample civilian Hispanics, blacks, and economically disadvantaged whites, and (3) a sample of 1,280 youths who were ages 17-21 as of January 1, 1979, and who were enlisted in the military as of September 30,1978. We use the random sample and the black and Hispanic oversamples and use the weights provided by the NLSY79, so that the weighted and analyses provided a representative sample of the U.S. population.

In the analyses, we control for information on family background, including family income and the highest grade completed by a person's mother and father. Specifically, Mother's Education and Father's Education equal the number of years of education of the mother and father respectively; and Family Income in 1979 measures the income of the individual's household in 1979, computed in 2010 dollars. (In the regressions we divide Family Income in 1979 by 100,000.) As shown in Table 2, the mean value is about $\$ 62,300$ and the median value is about $\$ 56,400$. There are missing values for Family Income in 1979. Consequently, when we use Family Income in 1979 as a regressor, we impute the sample mean and include a dummy variable that equals one for observations in which Family Income in 1979 is missing. When we use Family Income in 1979 to 
divide the sample, we do not impute a value for missing observations and instead use a smaller sample of individuals. Therefore the number of observations is not identical in these different specifications.

The major dependent variable is the binary indicator Attended College, which equals one if the individual attended college and zero otherwise. This variable equals one for individuals that attended college but did not graduate, those that graduated from college, and those that went on graduate school. As shown in Table 2, about half of the individuals attended college. We focus on whether the person attended college since it focuses on the decisions whether to go to college or work, which is the central decision in the theoretical framework. The results, however, are robust to focusing on whether the individual graduated from college or not.

Key explanatory variables are as follows:

AFQT Percentile is the individual's AFQT (Armed Forces Qualification Test) score as a percentile of the entire NLSY79 sample, where the AFQT Percentile is measured in 1980 and where 50 is the median of the NLSY79 sample and is 51 for our main regression sample due to missing values on parental education. The AFQT is a weighted sum of four tests of the ten-part Armed Services Vocational Aptitude Battery. We use the AFQT Percentile as a proxy of an individual's "ability to benefit from additional education." To guarantee that AFQT test scores were not influenced by school attendance, AFQT score is standardized by age of the individual at the time of the test (Cameron and Heckman, 1993; Neal and Johnson, 1996; and Altonji and Pierret, 2001). We exclude observations with missing AFQT scores, parental education, state of residency, and education attainment.

External Locus of Control Score (computed in 1980) measures the degree to which individuals believe that external factors, such as chance, fate, and luck control their lives relative to 
the degree that the individual has internal control over his or her life, where values range from four to sixteen - higher values signify more external control. The average value is 8.5

Self-Esteem Score (computed in 1980) measures the degree of approval or disapproval of one's self, where values range from six to 30- higher values signify greater self-approval. As shown in Table 2, the mean value of Self-Esteem Score is about 22.6, with a standard deviation of 4.

In some specifications, we use the Census Bureau's Current Population Survey (hereafter, CPS). We use the March Annual Demographic Survey files for the sample years 1976 to 2007 , taken from IPUMS. We use this much larger sample of individuals to compute the Mincerian returns to education as discussed below.

\section{Results}

\subsection{Bank deregulation and interest rates}

We begin by assessing the impact of bank deregulation on interest rates using the following specification:

$$
r_{j t}=\alpha D_{j t}+\beta D_{j t}^{2}+\delta_{j}+\delta_{t}+e_{j t}
$$

In the equation, $r_{j t}$ is a measure of real interest rates in state $j$ in year $t, \delta_{j}$ and $\delta_{t}$ are vectors of state and year fixed-effects, and $e_{j t}$ is the error term. The variables of interest, $D_{j t}$, and $D_{j t}^{2}$, equal the number of years since state $j$ deregulated (and zero before state $j$ deregulated) and the number of years since deregulation squared. In total, we have data for 48 states plus the District of Columbia. Consistent with the literature on bank branch deregulation, we eliminate Delaware and South Dakota because the structure of their banking systems were heavily affected by laws that made them centers for the credit card industry. 
Table 2 shows that intrastate bank deregulation was associated with a substantial reduction in interest rates when controlling for year and state effects. The significant, negative relationship between interest rates and bank deregulation only emerges when controlling for both year and state effects. This is consistent with the view that capital markets were segmented across the states of the United States and that one needs to abstract of national fluctuations in credit conditions to identify the independent impact of state-level deregulations on state interest rates.

\subsection{Bank Deregulation and College: Reduced Form Results}

We next assess the reduced form relationship between the removal of geographic restrictions on banks and college enrollment, where we differentiate individuals by AFQT scores and by parental education or family income. Since family income in one year might be a poor proxy for permanent income and since education is highly correlated with income, parental education might provide a more accurate signal of the family's long-run financial situation.

Based on the theoretical framework above, consider the linear-in-the-parameters probability model for whether a person attends college $\left(s_{i j}\right)$ :

$$
s_{i j}=\beta_{a} A F Q T_{i}+\beta_{D 1} D_{j, 79}+\beta_{D 2} D_{j, 79}^{2}+\beta_{X} X_{i j}+\varepsilon_{i j}
$$

where the subscript $i$ indicates a person and $j$ designates a state. We include one observation per person. We use AFQT to proxy for an individual's “ability to learn.” In many specifications, we split the sample by AFQT score to assess whether the impact of bank deregulation on educational choices differs by a student's "ability to learn." $D_{j, 79}$ is the number of years since deregulation for state $j$ in 1979 . We choose 1979 because it is the first year of the NLSY79 and it corresponds to a period in the lives of respondents when interest rates and credit conditions are likely to influence educational choices. Survey respondents are between the ages of 15 and 22 in 1979. By using a 
quadratic for years since deregulation, we allow for changes in credit conditions to have nonlinear effects on educational choices.

As additional regressors, $X_{i j}$, we include the following. External Locus of Control Score (computed in 1980) measures the degree to which individuals believe that external factors, such as chance, fate, and luck control their lives relative to the degree that the individual has internal control over his or her life. Self-Esteem Score (computed in 1980) measures the degree of approval or disapproval of one's self. Mother's and Father's Education measure the number of years of education of the mother and father respectively. Family Income in 1979 measures the income of the individual's family in 1979, computed in 2010 dollars and divided by $\$ 100,000$ (as a regressor). In several specifications, we split the sample based on parental education or family income to assess whether the impact of deregulation on college enrollment differs by these family characteristics. Furthermore, in all specifications, we control for regional, racial, gender and year of birth effects, and include a dummy variable that equals one if we imputed Family Income in 1979.

Tables 4 and 5 provide the regression results, where Table 4 provides the OLS estimates and Table 5 gives the Probit results. In both tables, column (1) provides the results for the full sample, columns (2) and (3) provides results splitting the sample between those with AFQT Percentile above and below 33, respectively. The NLSY79 sample mean value of AFQT Percentile is 50. In columns (4) and (5), we only consider individuals with AFQT scores above 33 and further split the sample by the education of the parents: column (4) includes individuals where either parent has 12 years or less of education and column (5) includes individuals where both parents have more than 12 years of education. Since the dependent variable is binary, we focus on the results using Probit regressions. The OLS regressions yield very similar inferences. For the Probit analyses, the reported coefficients are the estimated marginal effects, evaluated at the mean values of the regressors. The 
standard errors are clustered at the state level and corrected for heteroskedasticity using the HuberWhite adjustment.

Bank regulation boosted the probability that individuals with particular abilities and family traits attend college. In particular, bank deregulation has no effect on relatively low ability people, i.e., people with AFQT scores lower than 33 (Table 5, column 3). But, deregulation does have a positive impact on "able" students—-students with AFQT scores greater than 33 (Table 5, column 2). For instance, one year after deregulation, the probability of attending college rose by about 3.5 percent; five years after deregulation, the probability is 13 percent greater than before deregulation; 10 years after deregulation, the probability is 15 percent greater; and 15 years after, the probability is 8 percent greater than it was before the state deregulated restrictions on intrastate branching.

Furthermore, Table 5 shows that it is the able students from families in which both parents do not have more than 12 years of education that experience the biggest boost in the probability of going to college from bank deregulation. In particular, bank deregulation has no effect on attending college for individuals with AFQT scores above 33 but who are from families in which both parents have more than 12 years of education. But, bank deregulation has a very large effect on attending college for able students from less well-educated parents. The estimated effects are large. For instance, one year after deregulation, the probability of attending college rises by about 4.1 percent; five years after deregulation, the probability is 16 percent greater than before deregulation; 10 years after deregulation, the probability is 21 percent greater; and 15 years after, the probability is 17 percent greater than it was before the state deregulated restrictions on intrastate branching.

Besides the main results on bank deregulation, the analyses also show that AFQT and parental education are positively associated with higher college enrollment even when splitting the sample by AFQT and parental income. Self-esteem is also a good predictor of whether an individual 
attends college, even after conditioning on the array of individual, family, regional, and national factors included in the regressions.

Overall, the results from Tables 4 and 5 are consistent with the theoretical model presented above. To the extent that people with AFQT scores in the bottom third of the distribution are unlikely to benefit from college, it is unsurprising that an improvement in credit conditions does not influence their probability of attending college. Similarly, to the extent that able students from welleducated parents have a high probability of attending college, we would not expect bank deregulation to influence their likelihood of attending college either. Rather, theory and the evidence in Tables 4 and 5 indicate that changes in credit conditions influence a particular, though significant segment of society: able students from more disadvantaged family backgrounds. Table 6 continues these analyses by splitting the sample by different levels of Family Income in 1979, rather than by the education of the parents. In these analyses, we only consider "able" students, i.e., students with AFQT scores above 33. We present five Probit regressions of different samples, where we consider families with family income of (1) less than the $25^{\text {th }}$ percentile of family income in our sample, (2) more than the $25^{\text {th }}$ percentile, (3) more than the median, (4) more than the $75^{\text {th }}$ percentile, and (5) more than the $90^{\text {th }}$ percentile of family income in our full sample. We simply present the probit regression. The OLS regressions yield similar results.

We find that easing credit conditions — as proxied by intrastate bank deregulation—-boosted college enrollments for able students from middle class and upper-middle class families. As shown in Table 6, changing credit conditions had no impact on college enrollment for students with AFQT above 33 but who come from lower-income families (families with incomes below the $25^{\text {th }}$ percentile). And, changing credit conditions had no impact on college enrollment for able students from high-income families (families with incomes above the $90^{\text {th }}$ percentile). When we consider 
people from the middle and upper-middle of the income distribution, bank deregulation exerted a positive effect on college enrollment rates. For families with incomes above the median, the results from equation (3) indicate that five years after bank deregulation, an able person's probability of attending college are on average 20 percent greater; ten years after deregulation, they are onequarter greater; even 15 years after deregulation, the probability of an able person attending college are 15 percent greater than they were before deregulation.

\section{3. $2 S L S$}

We now employ a two-stage least squares (2SLS) Probit estimator to examine the impact of interest rates on the probability of attending college. That is, we estimate the following Probit equation of whether a person attends college or not $\left(s_{i j}\right)$ :

$$
\operatorname{Pr}\left(s_{i j}=1 \mid A F Q T_{i}, r_{j}, X_{i j}\right)=\Phi\left(\beta_{a} A F Q T_{i}+\beta_{r} r_{j}+\beta_{X} X_{i j}\right)
$$

where $\Phi()$ is the cumulative distribution function of the unit-normal distribution, $r_{j}$ is the real interest rate in 1979 in state $j$ and the other variables $(X)$ are as defined earlier. The excluded instrumental variables for $r_{j}$ are $D_{j, 79}$ and $D_{j, 79}^{2}$. Recall from Table 3 that bank deregulation helps account for cross-state, cross-time variation in interest rates. The first stage here is different from Table 3 because there is no time variation; there is one observation per person. However, the coefficients estimates from the first stage correspond with those presented in Table 3. In presenting the 2SLS Probit estimates, Table 7 uses a similar structure to that of Table 6, i.e., we split the sample by an individual's AFQT scores and family income.

For able students from middle and upper-middle class families, we find that a reduction in interest rates from bank deregulation during an individual's formative years is associated with an increase in the probability of attending college. For the full sample of individuals, there is not a 
significant relationship between attending college and interest rates (Table 7's column 1). And, there is not a significant relationship between interest rates and attending college when we only examine able students from lower-income families (families with incomes below the $25^{\text {th }}$ percentile), or when we only examine able students from high-income families (families with incomes above the $90^{\text {th }}$ percentile). Only when we consider able students from middle-class or upper-middle class families, i.e., when we restrict the sample to able students from families with incomes above the median or above the $75^{\text {th }}$ percentile, do we find that changes in interest rates triggered by bank deregulation are negatively and significantly associated with college attendance.

The economic magnitude of the relationship between interest rates and college attendance is large for the sub-sample of students with AFQT scores above 33 who are from middle and uppermiddle class families. The coefficient estimate for the sample of able students from families with incomes above the median indicates that a reduction in real interest rates of one percentage point is associated with an increase in the probability of attending college of almost 40 percent. For a not inconsequential segment of society, credit conditions are importantly linked with college attendance.

As noted earlier, we must interpret these 2SLS estimates cautiously because the instruments are unlikely to satisfy the exclusion restriction. Although there is no evidence that educational choices influence the timing of intrastate branch deregulation, there is evidence that intrastate branch deregulation influenced many features of the economy. Branch deregulation accelerated economic activity (Jayaratne and Strahan, 1996), reduced income inequality by disproportionately helping the poor (Beck, Levine, and Levkov, 2010), and reduced discrimination against black workers (Levine, Levkov, and Rubinstein, 2013). Thus, bank deregulation might influence college enrollment rates through a variety of channels beyond its effect on interest rates. It could very well 
be that deregulation boosted the demand for skilled workers and it is this "demand side" effect that drives the increase in college enrollment, not the "cost side" effect associated with the drop in interest rates.

Although the exclusionary restriction might not hold, two observations suggest that bank deregulation is pushing up college enrollment rates by reducing the cost of college, not just by increasing the demand for skilled workers. First, Beck, Levine, and Levkov (2010) show that bank deregulation increased the demand for unskilled workers, not skilled workers. Thus, bank deregulation does not seem to have increased the demand for skilled workers, which is the starting point of the "demand side" story.

Second, we now assess whether bank deregulation increased or decreased the returns to education. According to the demand side story, bank deregulation should increase the demand for skilled labor and hence the returns to education. In contrast, the supply side view suggests that bank deregulation lowered the costs of a college education, boosted the supply of college workers, and thereby lowered the returns to education. We assess which prediction holds in the data.

In Table 8, we regress the Mincerian returns to education on bank deregulation over the period from 1976 through 2002 using the following specification:

$$
M R_{j t}=\alpha D_{j t}+\beta D_{j t}^{2}+\delta_{j}+\delta_{t}+e_{j t}
$$

The dependent variable, $M R_{j t}$, equals the Mincerian Returns to education in state $j$ during year $t$ and is computed by regressing - by state and year - log wages on years of education and a quartic in potential work experience and collecting the estimated coefficient on years of education. To compute $M R_{j t}$, we use the CPS March Supplements and make the computations over the years 1976 through 2002, for the sample of full-time, full-year, white males between the ages of 25 and 55, and 
excluding people living in group quarters and working in either the military or agriculture. We use the CPS, rather than the NLSY79, because the CPS samples a much larger cross-section of individuals and we do not need the longitudinal nature of the NLSY79 to compute the returns to education at the state-year level.

As shown in Table 8, bank deregulation reduced the returns to education, after controlling for state and year effects. This is consistent with the "cost" side channel playing an important role, whereby bank deregulation lowered the costs of education, shifted out the supply curve of skilled workers, and reduced the returns to education. These findings are inconsistent with a purely "demand" side story, in which bank deregulation only boosted the demand for skilled labor, shifted out the demand curve, and increased the returns to education.

The results presented in Tables 7 and 8 suggest that by lowering the costs of a college education, bank deregulation boosted college enrollment rates among able students from middle and upper-middle class families. While these results do not indicate that bank deregulation only increased college enrollment by lowering costs, the results do suggest that bank deregulation increased college enrollments by lowering costs. Although we focus on the impact of deregulation on interest rates, it is possible that deregulation boosted college enrollment rates by increasing family incomes and thereby reducing the utility costs of funding a child's college education. While the income channel is feasible, Beck, Levine, and Levkov (2010) show that deregulation boosted the incomes of families in the lower third of the income distribution and we find that the major impact of deregulation on college enrollment rates occurs in families between the median and $90^{\text {th }}$ percentiles of the income distribution. Thus, while we cannot nail down the interest rate channel per se the evidence indicates that improvements in credit conditions triggered by bank deregulation increased college enrollment rates. 


\section{Conclusions}

In this paper, we find that intrastate branch deregulation - that lowered interest ratesboosted college enrollments among able students from families in which middle and upper-middle class families. Our findings suggest that credit conditions, the ability of an individual to benefit from college, and a family's financial circumstances combine to shape decisions about attending college. Banking reforms that ease credit conditions boost college enrollment rates among significant proportion of the population.

The analyses suggest that the functioning of the financial system exerts a powerful influence on shaping economic opportunities, as emphasized by Levine (2005). While many factors shape the economic opportunities available to a child, affording a good education is one of them. The results presented in this paper indicate that improvements in the functioning of the financial system help make education affordable to more students. 


\section{References}

Altonji, Joseph G. and Charles R. Pierret. 2001 "Employer Learning and Statistical Discrimination." Quarterly Journal of Economics 116(1) (February): 313-350.

Beck, Thorsten, Ross Levine, and Alexey Levkov. 2010. "Big Bad Banks? The Impact of U.S. Branch Deregulation on Income Distribution." Journal of Finance. 65(5): 1637-1667.

Becker, Gary S. 1957. The Economics of Discrimination. The University of Chicago Press, Chicago.

Becker, Gary S. 1967. Human Capital and the Personal Distribution of Income. Ann Arbor Michigan: University of Michigan Press.

Becker, G. 1975. Human Capital, 2nd Ed., New York, NY: Columbia University Press.

Becker, Gary S., and Nigel Tomes. 1979. "An Equilibrium Theory of the Distribution of Income and Intergenerational Mobility." The Journal of Political Economy, 87(6): 1153-89.

Becker, Gary S., and Nigel Tomes. 1986. "Human Capital and the Rise and Fall of Families." Journal of Labor Economics, 4(3, July): S1-39.

Behrman, Jere R. y P. Taubman (1990). The Intergenerational Correlation between Children's Adult Earnings and their Parent's Income: Results from the Michigan Panel Survey of Income Dynamics, The Review of Income and Wealth, 36(2), 115-127.

Belley, P., and L. Lochner (2007), The Changing Role of Family Income and Ability in Determining Educational Achievement", Working Paper.

Benabou, Roland. 1996. "Equity and Efficiency in Human Capital Investment: The Local Connection." Review of Economics Studies 63(2) (April): 237-264.

Ben-Porath, Yoram. 1967. "The Production of Human Capital and the Life Cycle of Earnings." Journal of Political Economy 75(4) (August): 352-365.

Brown, Meta, John K. Scholz, and Ananth Seshadri. 2012. "A New Test of Borrowing Constraints for Education." Review of Economics Studies 79(2): 511-538.

Cameron, Stephen V. and James J. Heckman. 1993. "The Nonequivalence of High School Equivalents." Journal of Labor Economics 11(1) (January): 1-47.

Cameron, Stephen V. and James J. Heckman. 1998. "Life Cycle Schooling and Dynamic Selection Bias: Models and Evidence for Five Cohorts of American Males ", The Journal of Political Economy, 106, 262-333.

Cameron, Stephen V. and James J. Heckman. 2001. "The dynamics of educational attainment for black, hispanic and white males", The Journal of Political Economy, 109, 455-499.

Cameron, S.V., and C. Taber. 2004). Estimation of Educational Borrowing Constraints Using Returns to Schooling", The Journal of Political Economy, 112, 132-182.

Card, D. 1999. The causal effect of education on earnings', in (O. Ashenfelter, and D. Card, eds.), Handbook of Labor Economics, Vol 3A. Amsterdam: Elsevier Science, North-Holland, pp.1801--63.

Card, D. 2001. Estimating the return to schooling: progress on some persistent econometric problems', Econometrica, vol. 69(5), pp. 1127--60. 
Card, D., and T. Lemieux 2001, Dropout and Enrollment Trends in the Post-War Period: What Went Wrong in the 1970s? in Risky Behavior among Youths: An Economic Analysis, Ed: Jonathan Gruber, Chicago, IL: University of Chicago Press, 439-482.

Carneiro, P., and J.J. Heckman. 2002, The Evidence on Interest rates in Post-Secondary Schooling", Economic Journal, 112, 989-1018.

Carneiro, P. and Heckman, J. 2003. Human capital policy', in (J. Heckman and A. Krueger), Inequality in America: What Role for Human Capital Policies, Cambridge: MIT Press.

Demirguc-Kunt, Asli and Ross Levine. 2009. "Finance and Inequality: Theory and Evidence." Annual Review of Financial Economics 1(1) (November): 287-318.

Ellwood, D., and T. Kane (2000), IWho Is Getting a College Education? Family Background and the Growing Gaps in Enrollment", in S. Danziger and J. Waldfogel (eds.), Securing the Future: Investing in Children from Birth to College, Russell Sage Foundation.

Griliches, Z. 1977. "Estimating the Returns to Schooling: Some Econometric Problems," Econometrica, vol. 45(1): 1-22.

Hauser R. 1993. "Trends in College Attendance Among Blacks' Whites and Hispanics" in Studies of Supply and Demand in Higher Education. C. Clotfelter and M. Rothschild eds. University of Chicago Press.

Heckman James, J. and Rubinstein Yona. 2001. "The Importance of Noncognitive Skills: Lessons From the GED Testing Program," American Economic Review, v91, n2, pp. 145-49.

Heckman, James J., Jora Stixrud, and Sergio Urzua. 2006. "The Effects of Cognitive and Noncognitive Abilities on Labor Market Outcomes and Social Behavior." Journal of Labor Economics 24 (July): 411-482.

Jayaratne, Jith, and Phillip E. Strahan. 1996. "The Finance-Growth Nexus: Evidence from Bank Branch Deregulation." Quarterly Journal of Economics 111 (August ): 639-670.

Kane, T. (1994). "College entry by blacks since 1970: the role of college costs, family background, and the returns to education", The Journal of Political Economy, vol. 102(5), pp. 878--911.

Kane, T. (2003). A Quasi-Experimental Estimate of the Impact of Financial Aid on College-Going NBER Working Paper No. 9703.

Kane, Thomas J. and Cecilia Elena Rouse.1999. "The Community College: Educating Students at the Margin between College and Work." Journal of Economic Perspectives 13(1) (Winter): 63-84.

Keane, M. (2002), Financial Aid, Borrowing Constraints, and College Attendance: Evidence from Structural Estimates", American Economic Review, 92, 293-297.

Keane, M., and K. Wolpin (2001), The Effect of Parental Transfers and Borrowing Constraints on Educational Attainment", International Economic Review, 42, 1051-1103.

Kroszner, Randall, and Phillip E. Strahan. 1999. "What Drives Deregulation? Economics and Politics of the Relaxation of Bank Branching Deregulation." Quarterly Journal of Economics 114 (November): 1437-67. 
Lang, Kevin, 1993. “Ability Bias, Discount Rate Bias, and the Return to Education,” Manuscript. Boston: Boston University, Department of Economics.

Lang, Kevin, Michael Manove, and William Dickens. 2005. "Racial Discrimination in Markets with Announced Wages." American Economic Review 95: 1327-40.

Levine, Ross. 2005. "Finance and Growth: Theory and Evidence." In Handbook of Economic Growth, edited by Philippe Aghion and Steven Durlauf, Amsterdam: North-Holland Elsevier Publishers.

Levine, Ross, Alexey Levkov, and Yona Rubinstein. 2013. "Bank Deregulation and Racial Inequality in America." Critical Finance Review, forthcoming.

Manski, C., and D. Wise (1983), College Choice in America, Cambridge, MA: Harvard University Press.

Mayer S. 1997. What Money Can't Buy, Harvard University Press.

Mincer, Jacob. 1974. Schooling, Experience and Earnings. New York: Columbia University Press.

Neal, Derek A., and William R. Johnson. 1996. "The Role of Premarket Factors in Black-White Wage Differences." Journal of Political Economy 104 (October): 869-895.

Shea, J. (2000). “Does parent's money matter?” Journal of Public Economics, 77(2), pp. 155--84.

White, Eugene N. 1982. "The Political Economy of Banking Regulation, 1864-1933." Journal of Economic History 42 (March): 33-40. 
TABLE 1: DATES OF INTRASTATE BANK BRANCH DEREGUALTION, BY STATES

\begin{tabular}{lllll}
\hline \hline State & Date & & State & Date \\
\cline { 1 - 2 } \cline { 5 - 5 } Alabama & 1981 & & Montana & 1990 \\
Alaska & 1960 & & Nebraska & 1985 \\
Arizona & 1960 & & Nevada & 1960 \\
Arkansas & 1994 & & New Hampshire & 1987 \\
California & 1960 & & New Jersey & 1977 \\
Colorado & 1991 & & New Mexico & 1991 \\
Connecticut & 1980 & & New York & 1976 \\
District of Columbia & 1960 & & North Carolina & 1960 \\
Florida & 1988 & & North Dakota & 1987 \\
Georgia & 1983 & & Ohio & 1979 \\
Hawaii & 1986 & & Oklahoma & 1988 \\
Idaho & 1960 & & Oregon & 1985 \\
Illinois & 1988 & & Pennsylvania & 1982 \\
Indiana & 1989 & & Rhode Island & 1960 \\
Iowa & 1999 & & South Carolina & 1960 \\
Kansas & 1987 & & Tennessee & 1985 \\
Kentucky & 1990 & & Texas & 1988 \\
Louisiana & 1988 & & Utah & 1981 \\
Maine & 1975 & & Vermont & 1970 \\
Maryland & 1960 & & Virginia & 1978 \\
Massachusetts & 1984 & & Washington & 1985 \\
Michigan & 1987 & West Virginia & 1987 \\
Minnesota & 1993 & & Wisconsin & 1990 \\
Mississippi & 1986 & & Wyoming & 1988 \\
Missouri & 1990 & & & \\
\cline { 1 - 2 } & & & & \\
\hline
\end{tabular}

Notes: The dates of intrastate bank branch deregulation are from Kroszner and Strahan 
TABLE 2: SUMMARY STATISTICS

\begin{tabular}{lccc}
\hline & Mean & Median & $\begin{array}{c}\text { Standard } \\
\text { Deviation }\end{array}$ \\
\hline Attended College & 0.52 & 1.00 & 0.50 \\
Years Since Deregulation & 3.65 & 0.00 & 7.16 \\
AFQT Percentile & 51.30 & 51.88 & 28.86 \\
External Locus of Control Score & 8.48 & 8.00 & 2.39 \\
Self-Esteem Score & 22.57 & 22.00 & 4.07 \\
Mother's Education & 11.68 & 12.00 & 2.79 \\
Father's Education & 11.83 & 12.00 & 3.57 \\
Family Income in 1979 (2010 dollars) & 62302 & 56430 & 42221 \\
Interest Rate & 5.29 & 5.17 & 2.68 \\
\hline
\end{tabular}

Notes: Attended College equals one if the individual attended college for any period of time and zero otherwise. Years Since Deregulation equals the number of years since the state deregulated restrictions on intrastate branch banking and is computed for the year 1979; AFQT Percentile is the individual's AFQT (Armed Forces Qualification Test) score as a percentile of the entire NLSY79 sample, which is measured in 1980, and where 50 is the median of the NLSY79 representative sample; External Locus of Control Score (computed in 1980) measures the degree to which individuals believe that external factors, such as chance, fate, and luck control their lives relative to the degree that the individual has internal control over his or her life, where values range from four to sixteen-higher values signify more external control; Self-Esteem Score (computed in 1980) measures the degree of approval or disapproval of one's self, where values range from six to 30higher values signify greater self-approval. Mother's and Father's Education measure the number of years of education of the mother and father respectively; and Family Income in 1979 measures the income of the individual's household in 1979, computed in 2010 dollars. In the regression tables, we divide Family Income in 1979 by $\$ 100,000$. Interest Rate is the annual real interest rate based on mortgage rates from a monthly survey of major lenders that are asked to report the terms and conditions on all conventional, single-family, fully amortized, purchase-money loans closed in the last five working days of the month. The data excludes FHA-insured and VA-guaranteed mortgages, refinancing loans, and balloon loans. The rate includes the amortization of initial fees, points, and charges over a 10-year period, which is the historical assumption of the average life of a mortgage loan and is computed by the Federal Housing Finance Board. We deflate by the national CPI. For variables from the NLSY79, the reported summary statistics use the NLSY79 sample weights. 


\begin{tabular}{lcccc}
\hline \hline & & & & \\
\cline { 2 - 5 } & $(1)$ & $(2)$ & $(3)$ & $(4)$ \\
\cline { 2 - 5 } Years Since Deregulation & -0.007 & -0.016 & -0.007 & $-0.025^{* *}$ \\
& $(0.012)$ & $(0.013)$ & $(0.009)$ & $(0.012)$ \\
Years Since Deregulation Squared & & & & \\
& -0.000 & -0.000 & 0.000 & 0.000 \\
Constant & $(0.000)$ & $(0.000)$ & $(0.000)$ & $(0.000)$ \\
& & & & \\
Year Effects & $5.17^{* * *}$ & $5.18^{* * *}$ & $2.02^{* * *}$ & $2.01^{* * *}$ \\
State Effects & $(0.068)$ & $(0.091)$ & $(0.052)$ & $(0.071)$ \\
& & & & Yes \\
Observations & No & No & Yes & Yes \\
R-square & No & Yes & No & 1274 \\
\hline
\end{tabular}

Notes: This table presents the results of four regressions, where the dependent variable equals the Interest Rate, which is computed at the state-year level. Interest Rate is the effective interest from on mortgages, which includes amortization of initial fees, points, and charges over a 10 -year period and is computed by the Federal Housing Finance Board. Consistent with previous research the sample includes data on the District of Columbia and all states except Delaware and South Dakota, which are dropped due to large concentrations of credit card banks. The sample covers the period from 1976 through 2002. Regressors: Years Since Deregulation equals the number of years since the state deregulated restrictions on intrastate branch banking. This varies at the state-year level. Standard errors are clustered at the state level and corrected using the Huber-White adjustment. The symbols ***, **, and * signify significance at the one, five, and ten percent levels respectively. 
(1) (2)

Sample:

All
(3)

(4)
(5)

\begin{tabular}{|c|c|c|c|c|c|}
\hline Sample: & All & AFQT $>33$ & AFQT $<33$ & $\begin{array}{c}\text { AFQT }>33 \text { and } \\
\text { Either parent } \leq 12 \\
\text { years of education }\end{array}$ & $\begin{array}{c}\text { AFQT }>33 \text { and } \\
\text { Both parents }>12 \\
\text { years of education }\end{array}$ \\
\hline Years Since Deregulation & $\begin{array}{c}0.025 * * \\
(0.012)\end{array}$ & $\begin{array}{c}0.035^{* * * *} \\
(0.012)\end{array}$ & $\begin{array}{c}0.003 \\
(0.014)\end{array}$ & $\begin{array}{c}0.041^{* * *} \\
(0.012)\end{array}$ & $\begin{array}{c}0.024 \\
(0.014)\end{array}$ \\
\hline Years Since Deregulation Squared & $\begin{array}{l}-0.001 * \\
(0.001)\end{array}$ & $\begin{array}{c}-0.002^{* * *} \\
(0.001)\end{array}$ & $\begin{array}{l}-0.000 \\
(0.001)\end{array}$ & $\begin{array}{c}-0.002^{* * *} \\
(0.001)\end{array}$ & $\begin{array}{l}-0.001 \\
(0.001)\end{array}$ \\
\hline AFQT Percentile & $\begin{array}{c}0.008 * * * \\
(0.000)\end{array}$ & $\begin{array}{c}0.009 * * * \\
(0.000)\end{array}$ & $\begin{array}{c}0.009 * * * \\
(0.001)\end{array}$ & $\begin{array}{c}0.009 * * * \\
(0.000)\end{array}$ & $\begin{array}{c}0.005^{* * *} \\
(0.001)\end{array}$ \\
\hline External Locus of Control Score & $\begin{array}{l}-0.001 \\
(0.002)\end{array}$ & $\begin{array}{c}-0.003 \\
(0.003)\end{array}$ & $\begin{array}{c}0.002 \\
(0.003)\end{array}$ & $\begin{array}{c}-0.004 \\
(0.003)\end{array}$ & $\begin{array}{c}0.002 \\
(0.005)\end{array}$ \\
\hline Self-Esteem Score & $\begin{array}{c}0.009 * * * \\
(0.002)\end{array}$ & $\begin{array}{c}0.007 * * * \\
(0.002)\end{array}$ & $\begin{array}{c}0.014^{* * *} \\
(0.003)\end{array}$ & $\begin{array}{c}0.007^{* * *} \\
(0.002)\end{array}$ & $\begin{array}{c}0.008 * * \\
(0.004)\end{array}$ \\
\hline Mother's Education & $\begin{array}{c}0.014^{* * *} \\
(0.003)\end{array}$ & $\begin{array}{c}0.021^{* * *} \\
(0.003)\end{array}$ & $\begin{array}{c}0.003 \\
(0.004)\end{array}$ & $\begin{array}{c}0.017 * * * \\
(0.004)\end{array}$ & $\begin{array}{c}0.006 \\
(0.006)\end{array}$ \\
\hline Father's Education & $\begin{array}{c}0.015^{* * *} \\
(0.002)\end{array}$ & $\begin{array}{c}0.018^{* * *} \\
(0.002)\end{array}$ & $\begin{array}{c}0.009 * * \\
(0.004)\end{array}$ & $\begin{array}{c}0.015^{* * * *} \\
(0.002)\end{array}$ & $\begin{array}{c}0.014 * * \\
(0.006)\end{array}$ \\
\hline Family Income in 1979 & $\begin{array}{c}0.153^{* * *} \\
(0.046)\end{array}$ & $\begin{array}{c}0.157^{* * * *} \\
(0.049)\end{array}$ & $\begin{array}{c}0.021 \\
(0.104)\end{array}$ & $\begin{array}{c}0.258 * * * \\
(0.072)\end{array}$ & $\begin{array}{c}0.021 \\
(0.071)\end{array}$ \\
\hline Observations & 8534 & 4737 & 3797 & 3836 & 901 \\
\hline R-square & 0.334 & 0.245 & 0.133 & 0.198 & 0.184 \\
\hline
\end{tabular}

Notes: This table presents the results of five OLS regressions, where the dependent variable equals one if the individual attended college and zero otherwise. There is one observation per person. Regressors: Years Since Deregulation equals the number of years since the state deregulated restrictions on intrastate branch banking and is computed for the year 1979; AFQT Percentile is the individual's AFQT (Armed Forces Qualification Test) score as a percentile of the entire NLSY79 sample, which is measured in 1980, and where 50 is the median of the NLSY79 representative sample; External Locus of Control Score (computed in 1980) measures the degree to which individuals believe that external factors, such as chance, fate, and luck control their lives relative to the degree that the individual has internal control over his or her life, where values range from four to sixteen—higher values signify more external control; Self-Esteem Score (computed in 1980) measures the degree of approval or disapproval of one's self, where values range from six to 30- higher values signify greater self-approval. Mother's and Father's Education measure the number of years of education of the mother and father respectively; and Family Income in 1979 measures the income of the individual's household in 1979, computed in 2010 dollars and divided by $\$ 100,000$. The regression includes regional, racial, and gender fixed effects, the individual's year of birth, and a dummy variable that equals one if we imputed Family Income in 1979 with the sample mean, due to missing values. Sample: Besides the core NLSY sample, we also include the supplementary dataset on Blacks and Hispanics. Standard errors are clustered at the state level and corrected using the Huber-White adjustment. The symbols ***, **, and * signify significance at the one, five, and ten percent levels respectively. 


\begin{tabular}{|c|c|c|c|c|c|}
\hline & (1) & (2) & (3) & (4) & (5) \\
\hline Sample: & All & AFQT $>33$ & AFQT $<33$ & $\begin{array}{c}\text { AFQT }>33 \text { and } \\
\text { Either parent } \leq 12 \\
\text { years of education }\end{array}$ & $\begin{array}{c}\text { AFQT }>33 \text { and Both } \\
\text { parents }>12 \text { years } \\
\text { of education }\end{array}$ \\
\hline Years Since Deregulation & $\begin{array}{c}0.031 \\
(0.019)\end{array}$ & $\begin{array}{c}0.035^{* * *} \\
(0.012)\end{array}$ & $\begin{array}{c}0.003 \\
(0.014)\end{array}$ & $\begin{array}{c}0.041^{* * *} \\
(0.012)\end{array}$ & $\begin{array}{c}0.024 \\
(0.014)\end{array}$ \\
\hline Years Since Deregulation Squared & $\begin{array}{l}-0.002 \\
(0.001)\end{array}$ & $\begin{array}{c}-0.002 * * * \\
(0.001)\end{array}$ & $\begin{array}{l}-0.000 \\
(0.001)\end{array}$ & $\begin{array}{c}-0.002 * * * \\
(0.001)\end{array}$ & $\begin{array}{c}-0.001 \\
(0.001)\end{array}$ \\
\hline AFQT Percentile & $\begin{array}{c}0.011^{* * * *} \\
(0.000)\end{array}$ & $\begin{array}{c}0.009 * * * \\
(0.000)\end{array}$ & $\begin{array}{c}0.009 * * * \\
(0.001)\end{array}$ & $\begin{array}{c}0.009 * * * \\
(0.000)\end{array}$ & $\begin{array}{c}0.005^{* * *} \\
(0.001)\end{array}$ \\
\hline External Locus of Control Score & $\begin{array}{l}-0.002 \\
(0.003)\end{array}$ & $\begin{array}{l}-0.003 \\
(0.003)\end{array}$ & $\begin{array}{c}0.002 \\
(0.003)\end{array}$ & $\begin{array}{l}-0.004 \\
(0.003)\end{array}$ & $\begin{array}{c}0.002 \\
(0.005)\end{array}$ \\
\hline Self-Esteem Score & $\begin{array}{c}0.013^{* * *} \\
(0.002)\end{array}$ & $\begin{array}{c}0.007^{* * *} \\
(0.002)\end{array}$ & $\begin{array}{c}0.014^{* * *} \\
(0.003)\end{array}$ & $\begin{array}{c}0.007^{* * *} \\
(0.002)\end{array}$ & $\begin{array}{c}0.008^{* *} \\
(0.004)\end{array}$ \\
\hline Mother's Education & $\begin{array}{c}0.021 * * * \\
(0.005)\end{array}$ & $\begin{array}{c}0.021^{* * *} \\
(0.003)\end{array}$ & $\begin{array}{c}0.003 \\
(0.004)\end{array}$ & $\begin{array}{c}0.017 * * * \\
(0.004)\end{array}$ & $\begin{array}{c}0.006 \\
(0.006)\end{array}$ \\
\hline Father's Education & $\begin{array}{c}0.022 * * * \\
(0.003)\end{array}$ & $\begin{array}{c}0.018^{* * *} \\
(0.002)\end{array}$ & $\begin{array}{l}0.009 * * \\
(0.004)\end{array}$ & $\begin{array}{c}0.015^{* * *} \\
(0.002)\end{array}$ & $\begin{array}{c}0.014^{* *} \\
(0.006)\end{array}$ \\
\hline Family Income in 1979 & $\begin{array}{c}0.264 * * * \\
(0.070)\end{array}$ & $\begin{array}{c}0.157^{* * *} \\
(0.049)\end{array}$ & $\begin{array}{c}0.021 \\
(0.104)\end{array}$ & $\begin{array}{c}0.258^{* * *} \\
(0.072)\end{array}$ & $\begin{array}{c}0.021 \\
(0.071)\end{array}$ \\
\hline $\begin{array}{l}\text { Observations } \\
\text { R-square }\end{array}$ & $\begin{array}{l}8534 \\
0.29\end{array}$ & $\begin{array}{l}4737 \\
0.25\end{array}$ & $\begin{array}{l}3797 \\
0.13\end{array}$ & $\begin{array}{l}3836 \\
0.20\end{array}$ & $\begin{array}{l}901 \\
0.18\end{array}$ \\
\hline
\end{tabular}

Notes: This table presents the results of five probit regressions, where the dependent variable equals one if the individual attended college and zero otherwise, and where the reported coefficients are the estimated marginal effects, evaluated at the mean values of the independent variables. There is one observation per person. Regressors: Years Since Deregulation equals the number of years since the state deregulated restrictions on intrastate branch banking and is computed for the year 1979; AFQT Percentile is the individual's AFQT (Armed Forces Qualification Test) score as a percentile of the entire NLSY79 sample, which is measured in 1980, and where 50 is the median of the NLSY79 representative sample; External Locus of Control Score (computed in 1980) measures the degree to which individuals believe that external factors, such as chance, fate, and luck control their lives relative to the degree that the individual has internal control over his or her life, where values range from four to sixteen—higher values signify more external control; Self-Esteem Score (computed in 1980) measures the degree of approval or disapproval of one's self, where values range from six to 30- higher values signify greater self-approval. Mother's and Father's Education measure the number of years of education of the mother and father respectively; and Family Income in 1979 measures the income of the individual's household in 1979, computed in 2010 dollars and divided by $\$ 100,000$. The regression includes regional, racial, and gender fixed effects, the individual's year of birth, and a dummy variable that equals one if we imputed Family Income in 1979 with the sample mean, due to missing values. Sample: Besides the NLSY sample, we also include the supplementary dataset on blacks and Hispanics. Standard errors are clustered at the state level and corrected using the Huber-White adjustment. The symbols ***, **, and * signify significance at the one, five, and ten percent levels respectively. 
(1)

$$
\text { AFQT }>33
$$

Sample:

Years Since Deregulation

Years Since Deregulation Squared

AFQT Percentile

External Locus of Control Score

Self-Esteem Score

Mother's Education

Father's Education

Family Income in 1979
(2)

(3)

(4)

(5)

$\begin{array}{ccccc}\text { AFQT }>33 & \text { AFQT }>33 & \text { AFQT }>33 & \text { AFQT }>33 & \text { AFQT }>33 \\ \text { and Family } & \text { and Family } & \text { and Family } & \text { and Family } & \text { and Family }\end{array}$ Income $<25 \%$ Income $>25 \%$ Income $>50 \%$ Income $>75 \%$ Income $>90 \%$

\begin{tabular}{ccccc}
\hline 0.036 & $0.043^{* *}$ & $0.055^{* * *}$ & $0.048^{* * *}$ & 0.018 \\
$(0.048)$ & $(0.019)$ & $(0.014)$ & $(0.006)$ & $(0.014)$ \\
-0.002 & $-0.002^{* *}$ & $-0.003^{* * *}$ & $-0.002^{* * *}$ & -0.001 \\
$(0.003)$ & $(0.001)$ & $(0.001)$ & $(0.000)$ & $(0.001)$ \\
$0.011^{* * *}$ & $0.010^{* * *}$ & $0.009^{* * *}$ & $0.007^{* * *}$ & $0.005^{* * *}$ \\
$(0.001)$ & $(0.001)$ & $(0.001)$ & $(0.001)$ & $(0.001)$ \\
$-0.016^{*}$ & -0.005 & -0.006 & -0.006 & -0.007 \\
$(0.009)$ & $(0.004)$ & $(0.004)$ & $(0.006)$ & $(0.005)$ \\
0.006 & $0.009^{* * *}$ & $0.007^{* *}$ & 0.005 & $0.005^{*}$ \\
$(0.006)$ & $(0.002)$ & $(0.003)$ & $(0.003)$ & $(0.003)$ \\
0.015 & $0.029^{* * *}$ & $0.024^{* * *}$ & $0.023^{* *}$ & $0.018^{* * *}$ \\
$(0.011)$ & $(0.005)$ & $(0.008)$ & $(0.009)$ & $(0.006)$ \\
$0.021^{* * *}$ & $0.022^{* * *}$ & $0.020^{* * *}$ & $0.022^{* * *}$ & $0.007 * *$ \\
$(0.007)$ & $(0.004)$ & $(0.004)$ & $(0.004)$ & $(0.003)$ \\
-1.238 & $0.365^{* * *}$ & $0.410^{* * *}$ & 0.233 & 0.089 \\
$(1.131)$ & $(0.093)$ & $(0.117)$ & $(0.153)$ & $(0.119)$ \\
& & & & \\
867 & 2904 & 1964 & 986 & 409 \\
0.23 & 0.23 & 0.24 & 0.27 & 0.38 \\
\hline
\end{tabular}

Observations

AFQT $>33$
and Family
Income $>75 \%$

AFQT $>33$

AFQT $>33$

$0.048 * * *$

$(0.014)$

$-0.001$

$(0.001)$

$(0.001)$

$-0.007$

(0.005)

$0.005^{*}$

(0.003)

$0.018 * *$

$0.007 *$

$(0.003)$

$(0.119)$

R-square

\begin{tabular}{rr}
867 & 2904 \\
0.23 & 0.23 \\
\hline
\end{tabular}

\begin{abstract}
Notes: This table presents the results of five probit regressions, where the dependent variable equals one if the individual attended college and zero otherwise, and where the reported coefficients are the estimated marginal effects, evaluated at the mean values of the independent variables. There is one observation per person. When designating the sample, Family Income $>X \%$ signifies the sample is restricted to individuals for which their Family Income levels in 1979 were above the X percentile of the sample. Regressors: Years Since Deregulation equals the number of years since the stat deregulated restrictions on intrastate branch banking and is computed for the year 1979; AFQT Percentile is the individual's AFQT (Armed Forces Qualification Test) score as a percentile of the entire NLSY79 sample, which is measured in 1980, and where 50 is the median of the NLSY79 representative sample; External Locus of Control Score (computed in 1980) measures the degree to which individuals believe that external factors, such as chance, fate, and luck control their lives relative to the degree that the individual has internal control over his or her life, where values range from four to sixteen-higher values signify more external control; Self-Esteem Score (computed in 1980) measures the degree of approval or disapproval of one's self, where values range from six to 30- higher values signify greater self-approval. Mother's and Father's Education measure the number of years of education of the mother and father respectively; and Family Income in 1979 measures the income of the individual's household in 1979, computed in 2010 dollars and divided by $\$ 100,000$. The regression includes regional, racial, and gender fixed effects, the individual's year of birth, and a dummy variable that equals one if we imputed Family Income in 1979 with the sample mean, due to missing values. Sample: Besides the core NLSY sample, we also include the supplementary dataset on blacks and Hispanics. Standard errors are clustered at the state level and corrected using the Huber-White adjustment. The symbols $* * *, * *$, and * signify significance at the one, five, and ten percent levels respectively.
\end{abstract}




\begin{tabular}{|c|c|c|c|c|c|c|}
\hline & (1) & $(2)$ & (3) & (4) & (5) & (6) \\
\hline Sample: & All & $\begin{array}{c}\text { AFQT }>33 \text { and Family } \\
\text { Income }<25 \%\end{array}$ & $\begin{array}{c}\text { AFQT }>33 \text { and Family } \\
\text { Income }>25 \% \\
\end{array}$ & $\begin{array}{c}\text { AFQT }>33 \text { and } \\
\text { Family Income }>50 \%\end{array}$ & $\begin{array}{c}\text { AFQT }>33 \text { and } \\
\text { Family Income }>75 \%\end{array}$ & $\begin{array}{c}\text { AFQT }>33 \text { and } \\
\text { Family Income }>90 \%\end{array}$ \\
\hline Interest Rate & $\begin{array}{l}-0.184 \\
(0.153)\end{array}$ & $\begin{array}{l}-0.049 \\
(0.384)\end{array}$ & $\begin{array}{l}-0.258 \\
(0.171)\end{array}$ & $\begin{array}{c}-0.385^{* *} \\
(0.150)\end{array}$ & $\begin{array}{c}-0.465^{* * *} \\
(0.079)\end{array}$ & $\begin{array}{l}-0.151 \\
(0.275)\end{array}$ \\
\hline AFQT Percentile & $\begin{array}{c}0.027 * * * \\
(0.001)\end{array}$ & $\begin{array}{c}0.030 * * * \\
(0.003)\end{array}$ & $\begin{array}{c}0.028 * * * \\
(0.002)\end{array}$ & $\begin{array}{c}0.030 * * * \\
(0.002)\end{array}$ & $\begin{array}{c}0.030 * * * \\
(0.002)\end{array}$ & $\begin{array}{c}0.038 * * * \\
(0.005)\end{array}$ \\
\hline External Locus of Control Score & $\begin{array}{l}-0.007 \\
(0.007)\end{array}$ & $\begin{array}{l}-0.043^{*} \\
(0.025)\end{array}$ & $\begin{array}{l}-0.015 \\
(0.010)\end{array}$ & $\begin{array}{l}-0.021 \\
(0.013)\end{array}$ & $\begin{array}{l}-0.029 \\
(0.025)\end{array}$ & $\begin{array}{l}-0.062 \\
(0.048)\end{array}$ \\
\hline Self-Esteem Score & $\begin{array}{c}0.032 * * * \\
(0.005)\end{array}$ & $\begin{array}{c}0.016 \\
(0.017)\end{array}$ & $\begin{array}{c}0.026 * * * \\
(0.007)\end{array}$ & $\begin{array}{c}0.024 * * \\
(0.012)\end{array}$ & $\begin{array}{c}0.025 \\
(0.016)\end{array}$ & $\begin{array}{l}0.047 * \\
(0.026)\end{array}$ \\
\hline Mother's Education & $\begin{array}{c}0.050 * * * \\
(0.014)\end{array}$ & $\begin{array}{c}0.043 \\
(0.029)\end{array}$ & $\begin{array}{c}0.085^{* * *} \\
(0.015)\end{array}$ & $\begin{array}{c}0.078 * * * \\
(0.024)\end{array}$ & $\begin{array}{c}0.097 * * \\
(0.040)\end{array}$ & $\begin{array}{l}0.146 * * \\
(0.064)\end{array}$ \\
\hline Father's Education & $\begin{array}{c}0.054 * * * \\
(0.007)\end{array}$ & $\begin{array}{c}0.055^{* * *} \\
(0.020)\end{array}$ & $\begin{array}{c}0.065^{* * *} \\
(0.011)\end{array}$ & $\begin{array}{c}0.068 * * * \\
(0.014)\end{array}$ & $\begin{array}{c}0.100 * * * \\
(0.016)\end{array}$ & $\begin{array}{c}0.064^{* *} \\
(0.029)\end{array}$ \\
\hline Family Income in 1979 & $\begin{array}{c}0.674 * * * \\
(0.180)\end{array}$ & $\begin{array}{l}-3.341 \\
(3.060)\end{array}$ & $\begin{array}{c}1.036 * * * \\
(0.269)\end{array}$ & $\begin{array}{c}1.309 * * * \\
(0.392)\end{array}$ & $\begin{array}{c}0.998 \\
(0.668)\end{array}$ & $\begin{array}{c}0.609 \\
(0.908)\end{array}$ \\
\hline Observations & 6909 & 867 & 2904 & 1964 & 986 & 409 \\
\hline
\end{tabular}

Notes: This table presents the results of six probit regressions, where the dependent variable equals one if the individual attended college and zero otherwise, and where the reported coefficients are the estimated marginal effects, evaluated at the mean values of the independent variables. There is one observation per person. When designating the sample, Family Income $>X \%$ signifies the sample is restricted to individuals for which their Family Income levels in 1979 were above the X percentile of the sample. Regressors: Years Since Deregulation equals the number of years since the state, in which the individual was living in 1979, deregulated restrictions on intrastate branch banking and is computed for the year 1979; AFQT Percentile is the individual's AFQT (Armed Forces Qualification Test) score as a percentile of the entire NLSY79 sample, which is measured in 1980 , and where 50 is the median of the NLSY79 representative sample; External Locus of Control Score (computed in 1980) measures the degree to which individuals believe that external factors, such as chance, fate, and luck control their lives relative to the degree that the individual has internal control over his or her life, where values range from four to sixteen--higher values signify more external control; Self-Esteem Score (computed in 1980) measures the degree of approval or disapproval of one's self, where values range from six to 30- higher values signify greater self-approval. Mother's and Father's Education measure the number of years of education of the mother and father respectively; and Family Income in 1979 measures the income of the individual's household in 1979, computed in 2010 dollars and divided by $\$ 100,000$. The regression includes regional, racial, and gender fixed effects, the individual's year of birth, and a dummy variable that equals one if we imputed Family Income in 1979 with the sample mean, due to missing values. Sample: Besides the core NLSY sample, we also include the supplementary dataset on blacks and Hispanics. Standard errors are clustered at the state level and corrected using the Huber-White adjustment. The symbols ***, **, and * signify significance at the one, five, and ten percent levels respectively. 
TABLE 8: BANK DEREGULATION AND THE RETURNS TO EDUCATION

\begin{tabular}{|c|c|c|c|c|}
\hline & $(1)$ & $(2)$ & (3) & (4) \\
\hline Years Since Deregulation & $\begin{array}{c}0.0021 * * * \\
(0.0006)\end{array}$ & $\begin{array}{c}0.0035^{* * * *} \\
(0.0003)\end{array}$ & $\begin{array}{c}0.0004 \\
(0.0005)\end{array}$ & $\begin{array}{c}-0.0010^{* *} \\
(0.0004)\end{array}$ \\
\hline Years Since Deregulation Squared & $\begin{array}{c}-0.0000 * * \\
(0.0000)\end{array}$ & $\begin{array}{c}-0.0000 * * \\
(0.0000)\end{array}$ & $\begin{array}{l}-0.0000 \\
(0.0000)\end{array}$ & $\begin{array}{c}0.0000 \\
(0.0000)\end{array}$ \\
\hline Constant & $\begin{array}{c}0.0733 * * * \\
(0.0027)\end{array}$ & $\begin{array}{c}0.0618 * * * \\
(0.0016)\end{array}$ & $\begin{array}{c}0.0592 * * * \\
(0.0032)\end{array}$ & $\begin{array}{c}0.0657 * * * \\
(0.0025)\end{array}$ \\
\hline Year Effects & No & No & Yes & Yes \\
\hline State Effects & No & Yes & No & Yes \\
\hline Observations & 1274 & 1274 & 1274 & 1274 \\
\hline R-square & 0.134 & 0.522 & 0.370 & 0.602 \\
\hline
\end{tabular}

Notes: This table presents the results of four regressions, where the dependent variable is Returns to Education . For each state-year, Returns to Education is computed by regressing log wages on years of education and a quartic in potential work experience and collecting the estimated coefficient on years of education, using data from CPS March Supplement, over the years 1976 through 2002, for the sample of full-time, full-year, white males between the ages of 25 and 55, and excluding people living in group quarters and working in either the military or agriculture. Consistent with previous research the sample includes data on the District of Columbia and all states except Delaware and South Dakota, which are dropped due to large concentrations of credit card banks. Regressors: Years Since Deregulation equals the number of years since the state deregulated restrictions on intrastate branch banking and is computed at the state-year level. Standard errors are clustered at the state level and corrected using the Huber-White adjustment. The symbols ${ }^{* * *}$, **, and ${ }^{*}$ signify significance at the one, five, and ten percent levels respectively. 